\title{
Prototipe Aplikasi Simpan Pinjam Pada Koperasi Darma Karya Pangkalpinang Babel
}

\author{
Sujono $^{[1]}$, Melati Suci Mayasari ${ }^{[2]}$, Koloniawan ${ }^{[3]}$ \\ Program Studi Sistem Informasi ${ }^{[1][3]}$, Program Studi Manajemen Informatika ${ }^{[2]}$ \\ STMIK Atma Luhur, Indonesia \\ email: sujono@atmaluhur.ac.id ${ }^{[1]}$,imeal_melati@atmaluhur.ac.id ${ }^{[2]}, 1322500101 @$ mahasiswa.atmaluhur.ac.id ${ }^{[3]}$
}

\begin{abstract}
Abstrak - Sistem manual menggunakan tenaga manusia dengan segala keterbatasannya belum mampu mengolah data dalam jumlah besar dan rumit secara tepat, akurat, efektif, dan efesien. Koperasi Darma Karya adalah salah satu koperasi yang masih menggunakan sistem manual sehingga dalam penyajian informasi lengkap terkait dokumentasi koperasi, informasi tentang anggota, informasi pencapaian koperasi serta evaluasi pencapaian koperasi dan tiap program kerja masih mengalami kendala waktu dan kevalidan data. Solusi yang tepat untuk mengatasi masalah tersebut adalah menggantikan sistem manual dengan aplikasi. Untuk merancang aplikasi digunakan model Prototipe dan metodologi UML(Unified Modeling Language). Dari rancangan ini menghasilkan sebuah model aplikasi yang menampilkan gambaran lengkap suatu sistem, sehingga aplikasi dapat dibangun sesuai kebutuhan untuk mengatasi masalah yang terjadi.
\end{abstract}

Kata kunci: model prototype, simpan pinjam, sistem informasi

\section{PENDAHULUAN}

Pada era globalisasi ini tentu saja penggunaan komputer sangatlah berpengaruh dalam dunia kerja. Apalagi untuk proses simpan pinjam pada Koperasi Darma Karya Pangkalpinang yang saat ini proses yang ada masih dilakukan secara tertulis, untuk memudahkan proses yang ada di Koperasi Darma Karya Pangkalpinang maka perlu sebuah aplikasi yang dapat mempermudah dalam proses penyimpanan dan peminjaman uang, juga diharapkan dapat memudahkan pencarian data maupun pembuatan laporan. Dengan menggunakan sebuah aplikasi maka masalah yang ada seperti data yang disimpan kurang rapi, sulitnya untuk mencari data yang berhubungan dengan simpan pinjam, lamanya dalam proses pembuatan laporan dapat diatasi dengan baik.

Untuk membuat aplikasi yang sesuai dengan kebutuhan diatas salah satunya adalah dengan membuat model aplikasi dalam bentuk prototipe yang dapat didiskusikan oleh pengguna sehingga kekurangan sistem yang akan dibangun dapat diketahui lebih awal. Berdasarkan masalah tersebut, sebuah sistem yang terkomputerisasi sangatlah diharapkan untuk merubah sistem yang masih menggunakan manual, dikarenakan proses simpan pinjam ini haruslah bisa mengetahui informasi dengan cepat mengenai simpan pinjam yang telah dilakukan oleh anggotanya dan diharapkan dengan menggunakan sebuah sistem yang terkomputerisasi tersebut semua masalah yang ditimbulkan dari sistem yang berjalan dapat teratasi dan proses yang berhubungan dengan simpan pinjam yang ada di Koperasi Darma Karya tersebut dapat dilakukan secara cepat, tepat, dan akurat sehingga diharapkan data yang berhubungan dengan proses simpan pinjam tersebut dapat disimpan secara rapi dan untuk lebih mempermudah dalam pencarian data yang berhubungan dengan simpan pinjam yang ada pada Koperasi Darma Karya.

\section{Metodologi Penelitian}

Dalam penelitian ini untuk menganalisa dan merancang aplikasi menggunakan pemrograman berorientasi objek. Sedangkan untuk melakukan pengembangan sistemnya menggunakan metode prototype. Prototype didefinisikan sebagai alat yang memberikan ide bagi pembuat maupun pemakai potensial tentang cara sistem berfungsi dalam bentuk lengkapnya, dan proses untuk menghasilkan sebuah prototype disebut prototyping.

\section{A. Analisa Berorientasi Obyek}

Analisis berorientasi obyek atau Object-Oriented Analisis (OOA) dimulai dengan menyatakan suatu masalah, analis membuat model situasi dari dunia nyata, menggambarkan sifat yang penting. Dalam menganalisa suatu sistem, analis harus bekerja dengan pihak yang membutuhkan sistem untuk memahami masalah tersebut dengan jelas. UML ( Unfied Modelling Language ) adalah salah satu alat bantu yang sangat handal di dunia pengembangan sistem yang berorientasi obyek. Hal ini disebabkan karena UML menyediakan bahasa pemodelan visual yang memungkinkan bagi pengembang sistem untuk membuat cetak biru atas visi mereka dalam bentuk yang baku, mudah dimengerti serta dilengkapi dengan mekanisme yang efektif untuk berbagi ( sharing ) dan mengkomunikasikan rancangan mereka dengan yang lain. Metode Booch dari Grady Booch sangat terkenal dengan nama metode Design Object Oriented. Metode ini menjadikan proses analisis dan design ke dalam empat tahapan interatif, yaitu identifikasi kelas-kelas dan obyek-obyek, identifikasi semantik dari hubungan obyek dan kelas tersebut, perincian 
interface dan implementasi. Keunggulan metode Booch adalah pada detil dan kayanya dengan notasi dan elemen [1].

\section{1) Activity Diagram}

Activity diagram menggambarkan proses bisnis dan urutan aktifitas dalam sebuah proses, yang mana dipakai pada business modelling untuk memperlihatkan urutan aktifitas proses bisnis karena bermanfaat untuk membantu memahami proses secara keseluruhan dalam memodelkan sebuah proses.

\section{2) Use Case Diagram}

Use case diagram menggambarkan kebutuhan sistem dari sudut pandang user dan memfokuskan pada proses komputerisasi. Sebuah use case dapat menggambarkan hubungan antara use case dengan actor. Secara umum use case adalah pola perilaku sistem dan urutan transaksi yang berhubungan yang dilakukan oleh satu actor.

\section{3) Class Diagram}

Class adalah sebuah spesifikasi yang jika diinstansiasi akan menghasilkan sebuah obyek dan merupakan inti dari pengembangan dan desain berorientasi obyek. Class menggambarkan keadaan (atribut/properti) suatu sistem, sekaligus menawarkan layanan untuk memanipulasi keadaan tersebut (metode/fungsi). Class diagram menggambarkan struktur dan deskripsi class, package dan obyek beserta hubungan satu sama lain seperti containment, pewarisan, asosiasi, dan lain-lain.

Class memiliki tiga area pokok, yaitu :

Nama (dan stereotype), Atribut, dan Metode.

\section{B. Model Protype}

Metode Prototype merupakan suatu paradigma baru dalam metode pengembangan perangkat lunak dimana metode ini tidak hanya sekedar evolusi dalam dunia pengembangan perangkat lunak, tetapi juga merevolusi metode pengembangan perangkat lunak yang lama yaitu sistem sekuensial yang biasa dikenal dengan nama SDLC atau waterfall development model. [2]

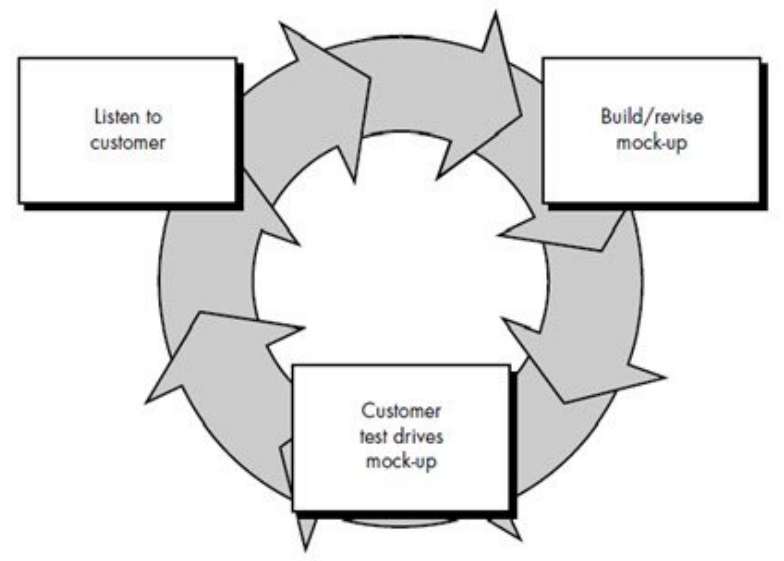

Gambar 1 : Model Prototype
Berikut adalah Tahapan - tahapan Proses Pengembangan dalam Model Prototype, yaitu :

1) Pengumpulan kebutuhan

Pelanggan dan pengembang bersama-sama mendefinisikan format seluruh perangkat lunak, mengidentifikasikan semua kebutuhan, dan garis besar sistem yang akan dibuat.

2) Membangun prototyping

Membangun prototyping dengan membuat perancangan sementara yang berfokus pada penyajian kepada pelanggan (misalnya dengan membuat input dan format output).

3) Evaluasi protoptyping

Evaluasi ini dilakukan oleh pelanggan, apakah prototyping yang sudah dibangun sudah sesuai dengan keinginan pelanggan atau belum. Jika sudah sesuai, maka langkah selanjutnya akan diambil. Namun jika tidak, prototyping direvisi dengan mengulang langkah-langkah sebelumnya.

4) Mengkodekan sistem

Dalam tahap ini prototyping yang sudah di sepakati diterjemahkan ke dalam bahasa pemrograman yang sesuai.

5) Menguji sistem

Setelah sistem sudah menjadi suatu perangkat lunak yang siap pakai, kemudian dilakukan proses Pengujian. Pengujian ini dilakukan dengan White Box, Black Box, Basis Path, pengujian arsitektur, dll.

6) Evaluasi Sistem

Pelanggan mengevaluasi apakah perangkat lunak yang sudah jadi sudah sesuai dengan yang diharapkan . Jika ya, maka proses akan dilanjutkan ke tahap selanjutnya, namun jika perangkat lunak yang sudah jadi tidak/belum sesuai dengan apa yang diharapkan, maka tahapan sebelumnya akan diulang.

7) Menggunakan sistem

Perangkat lunak yang telah diuji dan diterima pelanggan siap untuk digunakan.[2]

\section{Tinjauan Pustaka}

1) Sistem Informasi

Sistem menurut beberapa ahli dapat didefinisikan sebagai berikut:

- Menurut Stalling suatu sistem adalah suatu jaringan kerja dari prosedur-prosedur yang saling berhubungan, berkumpul bersama-sama untuk melakukan suatu kegiatan atau untuk menyelesaikan suatu sasaran yang tertentu.

- Dalam pengertian lain suatu sistem dapat diambil pengertian yang pada dasarnya adalah sekelompok unsur yang erat hubungannya satu dengan yang lain, 
yang berfungsi bersama-sama untuk mencapai tujuan tertentu.

\section{2) Koperasi}

Pengertian Koperasi berdasarkan UUD Nomor 25 tahun 1992 tentang PERKOPERASIAN bahwa koperasi adalah badan usaha yang beranggotakan orang-orang atau badan hukum koperasi dengan melandaskan kegiatannya berdasarkan prinsip koperasi sekaligus sebagai gerakan ekonomi rakyat yang berdasar atas asas kekeluargaan.

Pendapat lain menurut Arfinal Chaniago mengemukakan tentang perkoperasian bahwa koperasi sebagai suatu perkumpulan yang beranggotakan orang-orang atau badan hukum, yang memberikan kebebasan kepada anggota untuk masuk dan keluar, dengan bekerja sama secara kekeluargaan menjalankan usaha untuk mempertinggi kesejahteraan jasmaniah para anggotanya.[7]

\section{3) Otto Fajarianto:}

Metodologi dalam membangun perancangan sistem dengan menggunakan pemrograman berorientasi objek. Sedangkan untuk melakukan pengembangan sistemnya menggunakan metode prototype. Hasilnya adalah Sistem pelayanan akademik berbasis mobile ini adalah salah satu alternatif yang dapat dikembangkan oleh sebuah kampus untuk menjadi sarana penunjang pelayanan terhadap mahasiswa..[3]

\section{4) Syahrial:}

Model yang digunakan untuk merancang sistem adalah dengan pemodelan terstruktur dalam bentuk DFD dan ERD yang hasilnya adalah rancangan prototype sistem informasi koperasi berbasis web pada Koperasi Unit Desa Pandan Jaya Geragai.[4]

\section{5) Bella Hardiyana:}

Untuk metode pengembangan menggunakan metode terstruktur dengan beberapa alat bantu dan teknik pengerjaan seperti flowmap, diagram konteks, dan data flow diagram (DF), hasil dari penelitian ini adalah sebuah sistem informasi yang telah di uji metode pengujian black box .[5]

\section{6) Dwi Purnomo:}

Penelitian ini akan memberikan gambaran penggunaan model prototyping pada kegiatan pengembangan sistem informasi dengan menghasilkan sebuah prototype sebagai salah satu langkah awal sebuah kegiatan pengembangan sistem informasi.[6]

\section{HASIL DAN PEMBAHASAN}

Sistem berjalan yang ada pada Koperasi Darma Karya adalah sebuah sistem yang masih menggunakan banyak dokumen untuk pencatatan datanya. Beberapa proses yang ada di koperasi Darma Karya adalah Proses pendaftaran anggota, Proses penyetoran simpanan bulanan, Proses simpanan, Proses pengajuan pinjaman, Proses pencarian pinjaman, Proses pembayaran angsuran pinjaman, Proses laporan anggota, Proses laporan simpanan anggota, Proses laporan pinjaman anggota, Proses laporan angsuran pinjaman. Semua proses tersebut di gambar dengan Activity Diagram berikut ini:

\section{A. Activity Diagram}

Digunakan untuk menggambarkan proses yang terjadi. Berikut ini beberapa proses yang digambarkan antara lain :

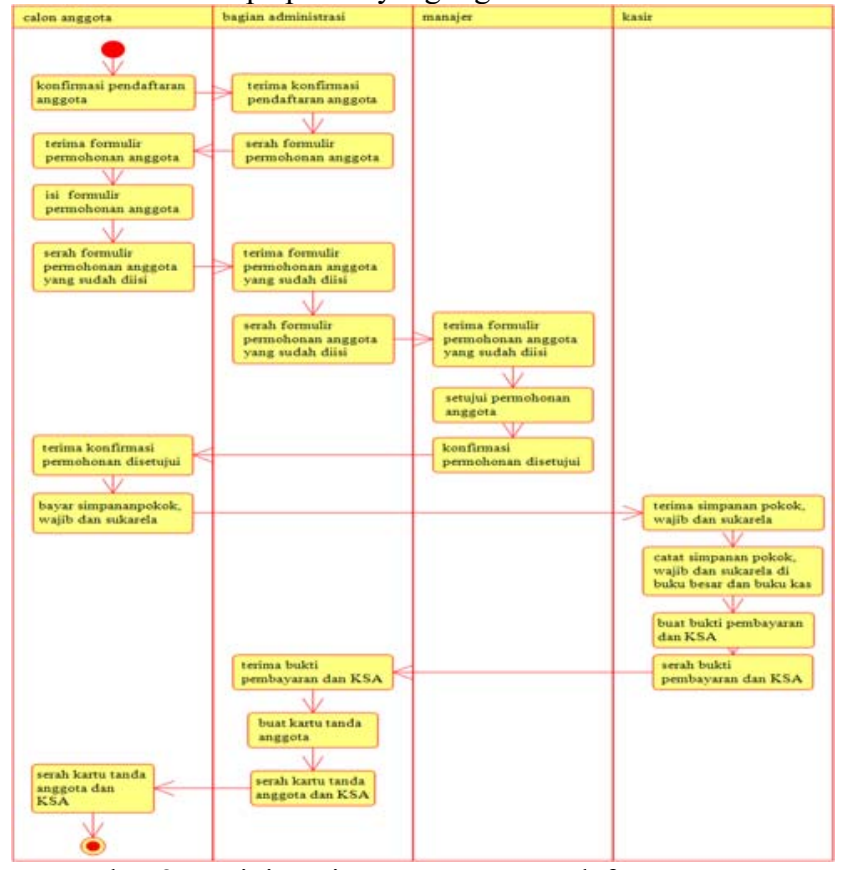

Gambar 2. Activity Diagram Proses Pendaftaran Anggota

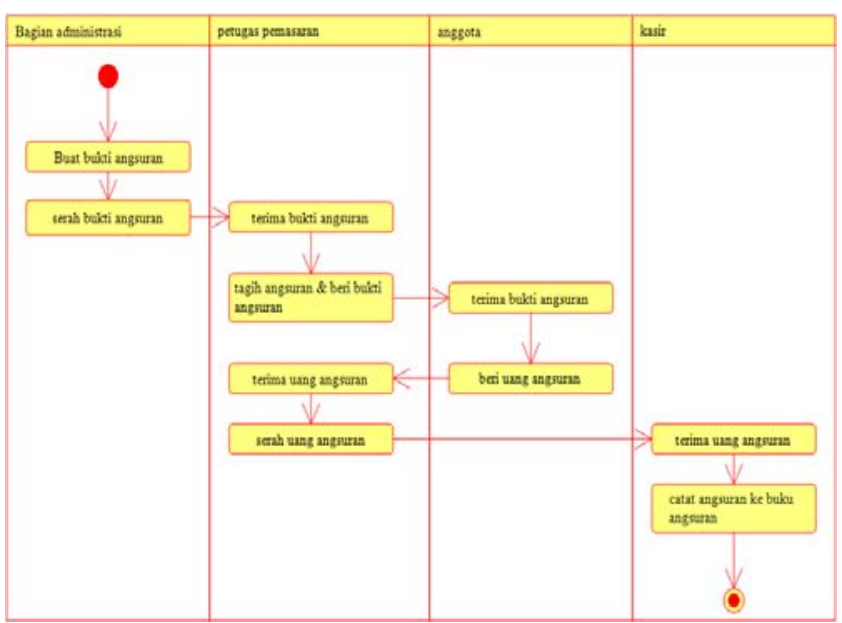

Gambar 3. Activity Diagram Proses Pembayaran Angsuran

ISSN $\quad: 2301-7988$ 


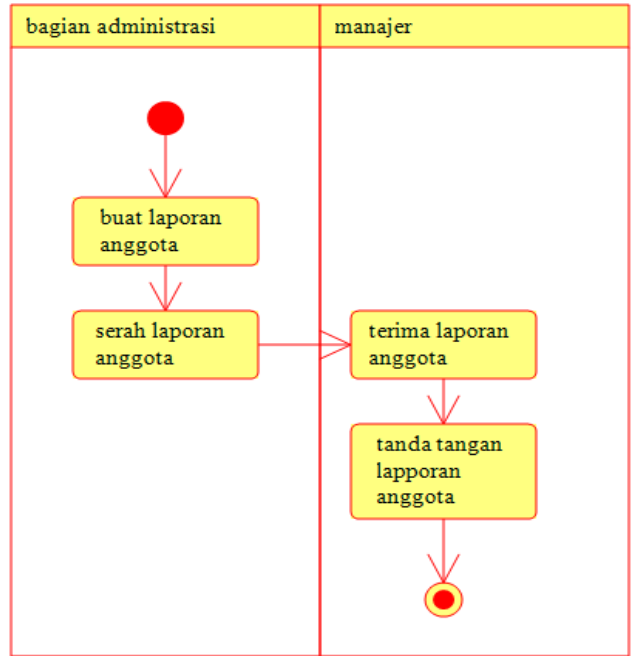

Gambar 4. Activity Diagram Proses Laporan Anggota

\section{B. Use Case Diagram}

Use case diagram digunakan untuk menggambarkan kebutuhan dan fungsionalitas sistem dari sudut pandang user. Adapun Use Case Diagram dalam penelitian ini sebagai berikut :

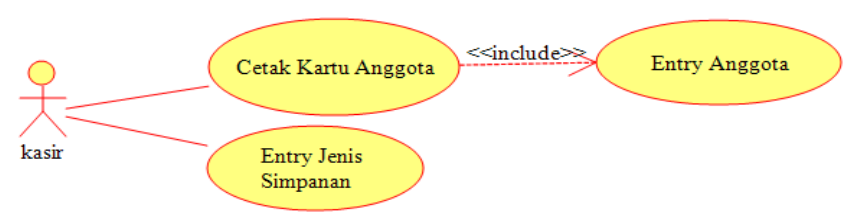

Gambar 5. Use Case Diagram Master

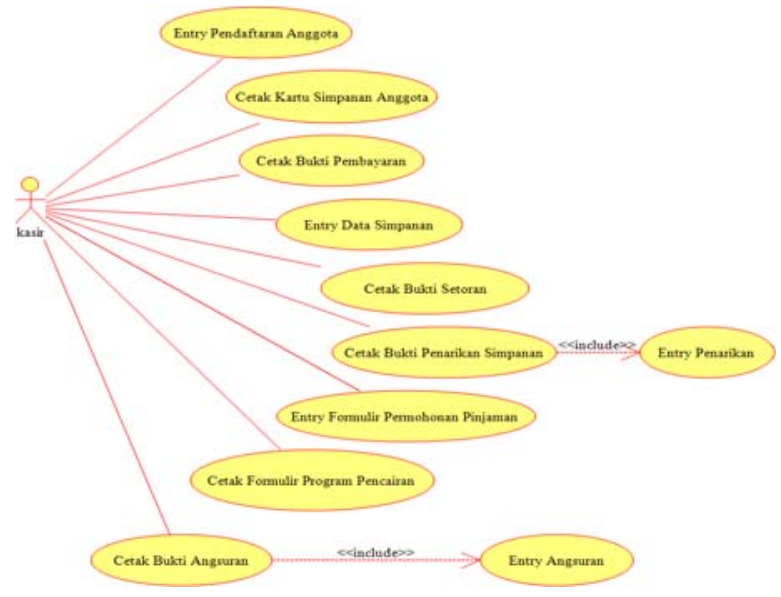

Gambar 6. Use Case Diagram Transaksi

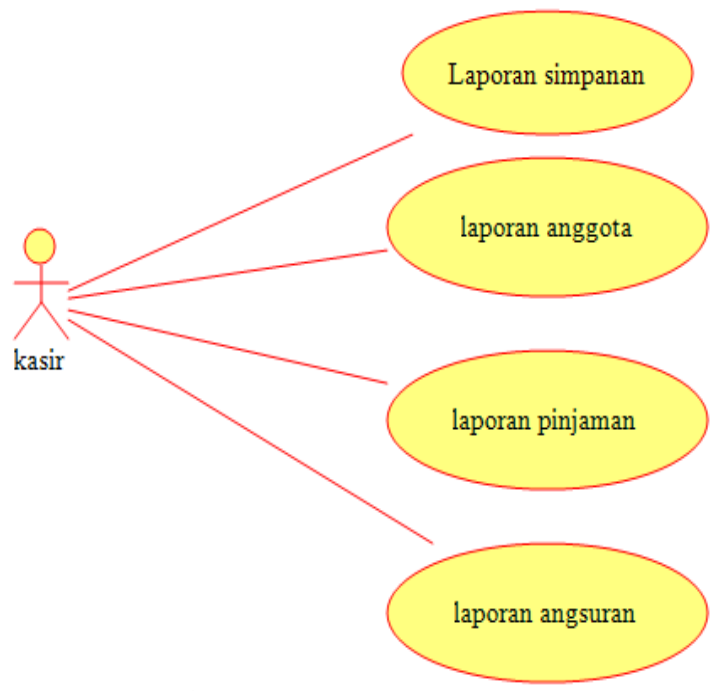

Gambar 7. Use Case Diagram Laporan

\section{Class Diagram}

Class diagram digunakan untuk membantu dalam visualisasi struktur kelas-kelas dari suatu sistem dan hubungan antar kelas dan penjelasan detail tiap kelas yang digambarkan seperti berikut :

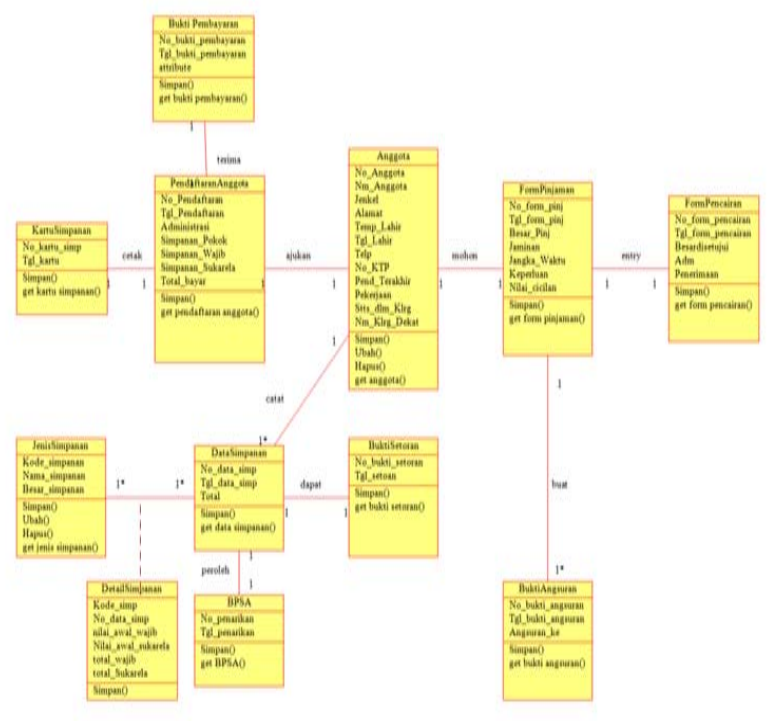

Gambar 8. Class Diagram

\section{Rancangan Basis Data}

Basis data merupakan komponen utama sistem informasi karena semua informasi untuk pengambilan keputusan berasal dari data yang ada di basis data. Dalam penelitian ini hubungan antar data dalam basis data digambar seperti berikut: 


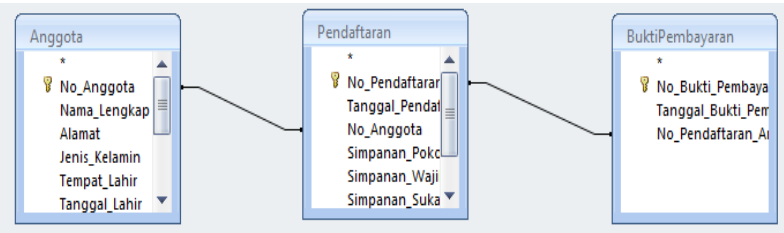

Gambar 9. Relationship Data Model

E. Rancangan AntarMuka

Berikut ini merupakan beberapa rancangan antarmuka Aplikasi Simpan Pinjam sebagai media interaksi antara pengguna dengan sistem :

\section{1) Form Entry Anggota}

Form ini digunakan untuk menambah, mengubah dan menghapus data-data mengenai data anggota.

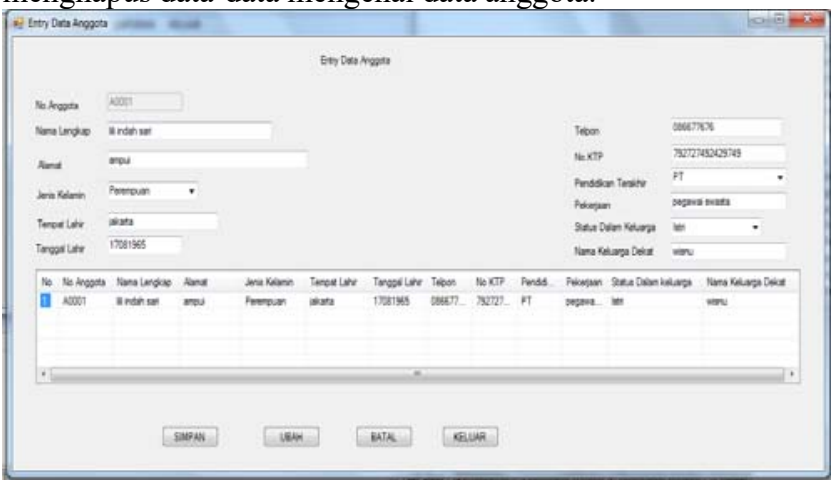

Gambar 10. Form Entry Data Anggota

2) Form Pendaftaran Anggota anggota.

Form ini digunakan untuk menambah data pendaftaran

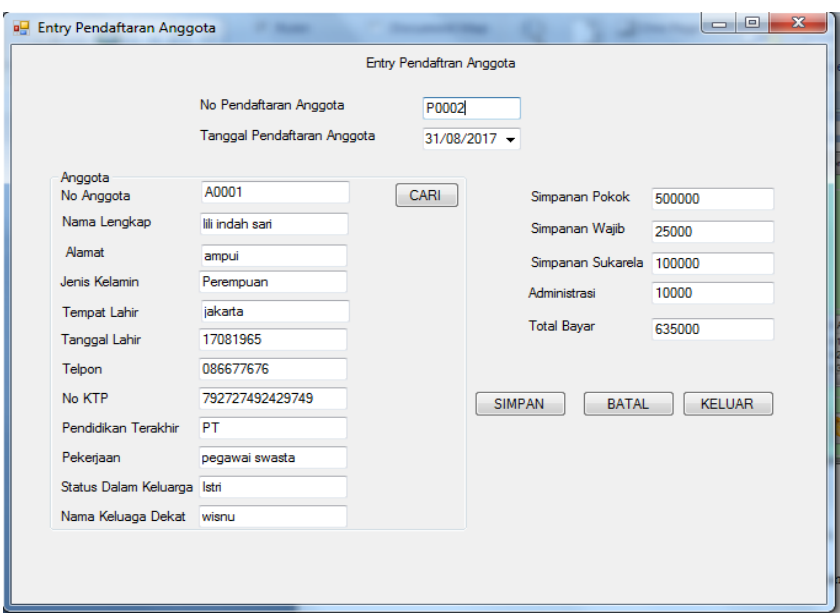

Gambar 11.Form Pendaftaran Anggota

3) Form Bukti Pembayaran

Form ini digunakan untuk mencetak bukti pembayaran anggota.

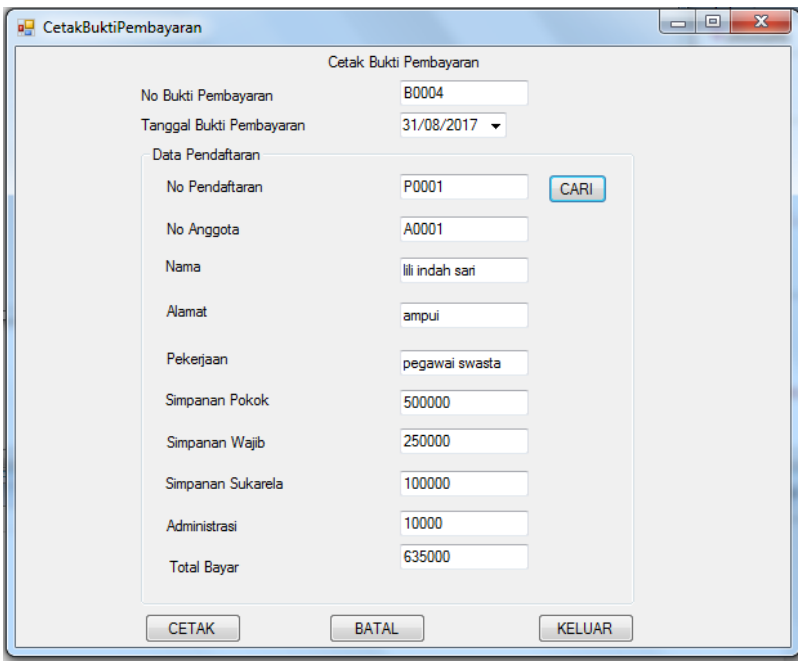

Gambar 12. Form Bukti Pembayaran

Output dari penginputan bukti pembayaran terlihat seperti gambar berikut :
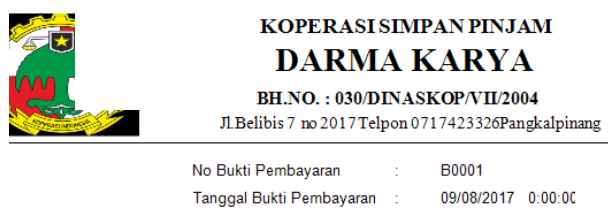

$\begin{array}{lll}\text { JAFTARAN } & : & \text { P0001 } \\ \text { IGOTA } & : & \text { A0001 } \\ & \vdots & \text { lili indah sari } \\ & : & \text { ampui } \\ \text { IAAN } & : & \text { pegawai swasta } \\ \text { AN POKOK } & : & 500000 \\ \text { AN WAJIB } & : & 250000 \\ \text { AN SUKARELA } & 100000 \\ \text { STRASI } & : & 10000 \\ \ldots . . . & & \end{array}$

Gambar 13. Bukti Pembayaran

\section{PENUTUP}

Berdasarkan penelitian dan uraian diatas maka dapat ditarik kesimpulan :

- Sistem baru dapat mengatas kendala waktu dan kebenaran data, sehingga proses menghasilkan informasi menjadi sangat baik.

- Pengolahan data anggota, pencarian data dan pembuatan laporan sudah dilakukan secara terkomputerisasi sehingga informasi yang dihasilkan menjadi lebih baik. 
- Rancangan aplikasi sistem informasi ini dapat digunakan untuk membantu bagian kasir dalam melakukan proses pendaftaran anggota, proses peminjaman, pembayaran angsuran, dan pembuatan laporan yang dapat meminimalkan tingkat kesalahan yang biasanya terjadi dalam sistem manual.

- $\quad$ Penggunaan sistem informasi yang baru ini tidak akan merusak sistem yang selama ini berjalan di Koperasi Darma Karya Pangkalpinang, tetapi dengan sistem ini diharapkan dapat lebih mendukung kinerja proses pengolahan data pada sistem, sehingga lebih efisien.

- Kelebihan dari sistem ini jika diterapkan oleh Koperasi Darma Karya yaitu bisa lebih menghemat waktu untuk pencarian data dan penginputan data, serta dapat menyajikan informasi secara cepat, tepat, dan akurat.

\section{DAFTAR PUSTAKA}

[1] Nugroho, Adi.(2007). Analisis \& Perancangan Sistem Informasi Dengan Metodelogi Berorientasi Objek Ed.Revisi, Informatika

[2] Angon,"Macam-Macam Model Pengembangan Perangkat Lunak dan Contoh Penerapan", 2016, https://www.angon.co.id/news/uncategorized/model-modelpengembangan-perangkat-lunak-beserta-contoh-penerapannya, 15 April 2016

[3] Fajarianto, Otto,2016, "Prototype Pelayanan Akademik Terhadap Komplain Mahasiswa Berbasis Mobile". JURNAL LENTERA ICT, Vol.3 No.1, Mei 2016 / ISSN 2338-3143

[4] Syahrial, Sharipuddin, 2016, "Analisis Dan Perancangan Sistem Informasi Koperasi Berbasis Web Pada Koperasi Unit Desa Pandan Jaya Geragai”. Jurnal Manajemen Sistem Informasi Vol 1 No. 1, September 2016 ISSN : 2540-8011

[5] Hardiana, Bella., Gusdiono, Eko. 2014 " SISTEM INFORMASI SIMPAN PINJAM (Studi Kasus : Koperasi KSU Tandangsari Tanjungsari Kabupaten Sumedang)". JAMIKAJurnal Manajemen Informatika UNIKOM.

[6] Purnomo, Dwi, 2017. " Model Prototyping Pada Pengembangan Sistem Informasi”. JIMP - Jurnal Informatika Merdeka Pasuruan Vol.2 No.2 Agustus 2017 ISSN 2503-1945.

[7] Pratiwi., Herliana, Asti, 2015. "Analisis Dan Desain Sistem Informasi Simpan Pinjam Pada Koperasi Sejahtera Bersama Bandung”. Jurnal Informatika. Vol. II No. 1 April 2015. 